\title{
Assessment of lonizing Radiation Effects on the Hematological Parameters of Radiation-Exposed Workers
}

\author{
H.N.E. Surniyantoro ${ }^{* 1}$, T. Rahardjo ${ }^{1}$, Y. Lusiyanti ${ }^{1}$, N. Rahajeng ${ }^{1}$, A.H. Sadewa ${ }^{2}$, \\ P. Hastuti ${ }^{2}$ and H. Date ${ }^{3}$ \\ ${ }^{I}$ Center for Technology of Radiation Safety and Metrology, National Nuclear Energy Agency \\ Jl. Lebak Bulus Raya 49, Jakarta 12070, Indonesia \\ ${ }^{2}$ Department of Biochemistry, Faculty of Medicine, Universitas Gadjah Mada, \\ Jl. Farmako Sekip Utara, Yogyakarta 55281, Indonesia \\ ${ }^{3}$ Faculty of Health Sciences, Hokkaido University, Kita-12, Nishi-5, Kitaku, Sapporo 060-0812, Japan
}

\section{ARTICLE INFO}

Article history:

Received 1 December 2018

Received in revised form 5 March 2019

Accepted 11 March 2019

\section{Keywords:}

Ionizing radiation

Hematological parameters

Long-term exposure

Blood cells count

Radiation-exposed workers

\begin{abstract}
A B S T R A C T
Long-term exposure to low doses of ionizing radiation may adversely affect human cells and tissues of hospital radiation workers, especially peripheral blood cell count. Blood cell count analysis is a useful screening test in a routine medical checkup. A high or low blood cells count even in a healthy-looking subject leads to the suspicion of disease and it should prompt further investigations. This study was aimed to assess the effects of ionizing radiation on the hematological parameters of radiation workers at several governmental hospitals in Indonesia and correlation between years of employment and equivalent dose on one hand and the hematological parameters on the other. It included 74 medical radiation workers occupationally exposed to low doses of ionizing radiation at the Unit of Radiology and Radiotherapy and 83 controls. Fourteen hematological parameters were measured by $\mathrm{ABX}$ Micros 60 Hematology analyzer and the correlation between years of employment and equivalent dose as well as hematological parameters on radiation-exposed workers were tested by linear regression analysis test. Our study reported that red blood cell and monocyte counts were significantly higher in radiation-exposed workers compared to controls, whereas white blood cells, hematocrit, mean corpuscular volume, and lymphocytes values were significantly lower in radiation-exposed workers. A significant correlation was observed between equivalent dose and red blood cells (RBCs) parameter $(\mathrm{P}=0.001)$ with a decline in $\mathrm{RBC}$ level of $0.541 \times 10^{6} / \mu \mathrm{L}$ per $1 \mathrm{mSv}$ increase of radiation dose. The present study recommends that further studies should use a larger sample size and include various independent variables (genetic polymorphism, chromosome aberration, micronucleus frequency) to study the long-term effects of low-dose radiation exposure on radiation-exposed workers.
\end{abstract}

() 2019 Atom Indonesia. All rights reserved

\section{INTRODUCTION}

Several research activities on the effects of radiation on human cells or tissues has been conducted lately, especially on biochemical, cytogenetic and hematological parameters [1]. Exposure to long-term ionizing radiation (IR) can affect cell division, especially in sensitive tissues

\footnotetext{
${ }^{*}$ Corresponding author.

E-mail address: harry_nes@batan.go.id

DOI: https://doi.org/10.17146/aij.2019.916
}

such as bone marrow, skin, and gastrointestinal organs. Disruption in the bone marrow will reduce the production of blood, which functions as an oxygen transporter and protects against viruses and bacteria. Previous studies by Ismail and Jaafar (2011) showed that changes in blood function due to ionizing radiation are affected by the duration of exposure (years of employment) and effective dose. These investigations have demonstrated that stochastic effects or longer-term effects may appear after exposure to low level radiation [2-4]. 
The effects of ionizing radiation on cells or tissues occur both directly and indirectly. The direct effect of exposure to ionizing radiation is the direct ionization of cell macromolecules, while the indirect effect of ionizing radiation exposure includes interaction with water that produce free radicals as a result of water radiolysis. About $75 \%$ of the mass of cells or tissues consists of water. Cell damage due to free radicals will increase due to the presence of oxygen which will form various types of reactive oxygen species (ROS). ROS can interfere with the function and stability of deoxyribonucleic acid (DNA), proteins, and lipids, resulting in metabolic disorders and cell death [5].

The effects of IR on hematopoietic cells occur directly by destroying hematopoietic stem cells or by changing the cell's ability to maintain hematopoiesis function in vivo and in vitro. It can induce a reduction in the number of hematopoietic cells through a reduction in bone marrow production, redistribution, and apoptosis [6]. Shao et al. divided the effects of ionizing radiation on the hematopoietic stem cells (HSCs) into direct and indirect effects. The direct effects of IR include damage to HSCs through apoptosis, cells differentiation, and aging/decrease of function. All of these mechanisms lead to HSC damage, as shown in Fig. 1. HSC damages occur at a dose of 2-7.5 Gy, gastrointestinal damages at doses $>5.5$ Gy, and neurovascular damages at doses $>20$ Gy. This shows that the HSC is the most sensitive cell to ionizing radiation compared to other cells [7].

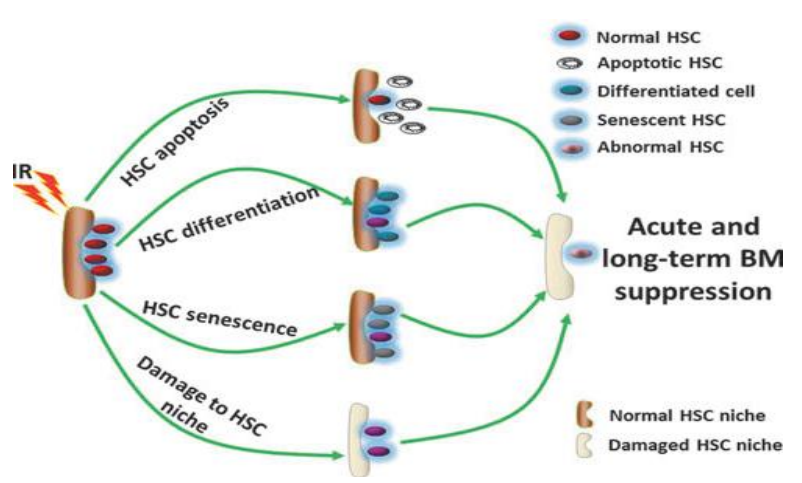

Fig. 1. Mechanism of hematopoietic stem cell damage by ionizing radiation [6].

One of the tests in a medical checkup is the calculation of blood cells. High or low blood cell counts indicate the level of individual health. Previous studies have shown negative effects of ionizing radiation exposure on hematological parameters such as hemoglobin, erythrocyte, hemoglobin, leukocyte, and platelet levels [8]. In addition to hematological parameters, damages due to ionizing radiation exposure are also evidenced by damages at the molecular level, such as DNA and chromosome damages. A previous study by Surniyantoro et al. (2018) showed that micronuclei, as a biomarker of DNA damage, were significantly higher in the exposed workers than in controls $(\mathrm{P}=0.001)[9,10]$.

Research by Alnahhal et al. (2017) showed no significant differences between RBC, WBC, and platelets levels in the control group and workers, and no correlation between the duration of work and hematological parameters. The same results are also shown by Oskouii et al. (2013), Khorrami et al. (2015), and Shaffie et al. (2016) in the Iranian population [6,11-13]. On the other hand, several recent studies by Shahid et al. (2014) and Klucinski et al. (2014) stated that there were significant differences in lymphocyte counts between the control population and radiation workers $[14,15]$. This study was aimed to assess the effects of ionizing radiation on the hematological parameters of radiation workers at governmental hospitals in Indonesia and correlation between the number of years of employment and the equivalent dose on one hand and the hematological parameters on the other.

\section{EXPERIMENTAL METHODS}

\section{Study population}

Research ethics approval was obtained from the National Commission on Ethics of Health Research, Agency for Health Research and Development, Ministry of Health, Indonesia, No. LB.02.01/5.2.KE.079/2017. The study included 74 medical radiation workers occupationally exposed to low doses of ionizing radiation in the Unit of Radiology and Radiotherapy at four governmental hospitals in Indonesia, i.e., Dr. Sutomo General Hospital, Surabaya; M. Djamil General Hospital, Padang; Sanglah General Hospital, Bali; and Harapan Kita General Hospital, Jakarta. The controls group members $(83$ subjects) were chosen from non-radiation workers in each hospitals. The control workers were staffs in these hospitals who were not exposed to radiation or work without devices that emit the radiation exposure. All of the subjects gave their informed consent after being informed of the study scope and experimental details. Standardized questionnaires were administered to all of the participants to determine their sociodemographic characteristics, such as gender, age, smoking status, years of employment, and equivalent dose ( $\mathrm{mSv})$. 


\section{Blood samples collection}

Blood samples of all individuals were collected ( $3 \mathrm{~mL}$ of blood from each subject) using a vacutainer containing an anticoagulant (EDTA) and then inverted slowly to prevent blood clots. The obtained blood samples were stored in the refrigerator at $4{ }^{\circ} \mathrm{C}$ until used. Hematological parameters (HPs) were measured by ABX Micros 60 hematology analyzer according to laboratory standards at the clinical laboratory of Center for Technology of Radiation Safety and Metrology, National Nuclear Energy Agency of Indonesia.

\section{Hematological parameters (HPs) analysis}

Fourteen hematological parameters were measured for this study, namely hemoglobin ( $\mathrm{Hb}$ in $\mathrm{g} / \mathrm{dL}$ ), red blood cells (RBC in count $\times 10^{6} / \mu \mathrm{L}$ ), white blood cells (WBC in count $\times 10^{3} / \mu \mathrm{L}$ ), platelet count (PLT in count $\times 10^{3} / \mu \mathrm{L}$ ), hematocrit (HCT in \%), mean corpuscular volume (MCV in $\mu \mathrm{m}^{3}$ ), mean corpuscular hemoglobin (MCH in pg), mean corpuscular hemoglobin concentration (MCHC in $\mathrm{g} / \mathrm{dL}$ ), red blood cells distribution width (RDW in \%), mean platelet volume (MPV in $\mu \mathrm{m}^{3}$ ), platelet distribution width (PDW in \%), lymphocytes (LYM in count $\times 10^{3} / \mu \mathrm{L}$ ), monocytes (MON in count $\times 10^{3} / \mu \mathrm{L}$ ), and granulocytes (GRAN in count $\times 10^{3} / \mu \mathrm{L}$ ). They were analyzed in all groups. The laboratory used for analysis had been accredited by the National Accreditation Committee of Indonesia (KAN) based on SNI ISO/IEC 17025: 2008 for Testing Laboratories (number LP-206-IDN) and Calibration Laboratories (number LK-142-IDN).

\section{Statistical analysis}

The statistical analysis of the data was conducted with SPSS version 16.0 for Windows. An independent-samples T-test was conducted on the mean values of fourteen hematological parameters to analyze those parameters which show a significant difference between all radiationexposed workers and controls. A Mann-Whitney U test was conducted on those hematological parameters to check if the data distribution was not normal. The correlation of years of employment and equivalent dose to HPs on exposed workers were tested by linear regression analysis test. A significant correlation is indicated by the value of $\mathrm{P}<0.05$.

\section{RESULTS}

The background information for all individuals included in this study is presented in Table 1 .
Among all radiation-exposed workers $(n=74)$, most of the workers were male (40). The group's age range was 25-59 years (mean $=44.43 \pm 9.38$ ). Among all controls $(n=83)$, most were female (48). The control's age range was 19-68 years (mean $=42.54 \pm 12.88)$. Of all subjects, seven radiation workers $(9.46 \%)$ and 31 controls $(37.35 \%)$ had smoking habits.

Table 1. Demographic characteristics of the study population.

\begin{tabular}{|c|c|c|c|}
\hline & Exposed & Controls & Total \\
\hline Sample size $(\mathrm{N})$ & 74 & 83 & 157 \\
\hline $\begin{array}{l}\text { Gender } \\
\text { Males }(\%) \\
\text { Females }(\%)\end{array}$ & $\begin{array}{l}40(54.05) \\
34(45.95)\end{array}$ & $\begin{array}{l}35(42.17) \\
48(57.83)\end{array}$ & $\begin{array}{l}75(47.77) \\
82(52.23)\end{array}$ \\
\hline $\begin{array}{l}\text { Age (years) } \\
\text { Mean } \pm \text { SD } \\
\text { Range }\end{array}$ & $\begin{array}{l}44.43 \pm 9.38 \\
25-59\end{array}$ & $\begin{array}{l}42.54 \pm 12.88 \\
19-68\end{array}$ & $\begin{array}{l}43.43 \pm 11.41 \\
19-68\end{array}$ \\
\hline $\begin{array}{l}\text { Smoking status } \\
\text { Never }(\%) \\
\text { Current }(\%)\end{array}$ & $\begin{array}{l}67(90.54) \\
7(9.46)\end{array}$ & $\begin{array}{l}52(62.65) \\
31(37.35)\end{array}$ & $\begin{array}{ll}119 & (75.80) \\
38 & (24.20)\end{array}$ \\
\hline $\begin{array}{l}\text { Years } \\
\text { of employment } \\
\text { Mean } \pm \text { SD } \\
\text { Range }\end{array}$ & $\begin{array}{l}16.95 \pm 8.46 \\
2-35\end{array}$ & - & - \\
\hline $\begin{array}{l}\text { Equivalent dose } \\
\text { (mSv) } \\
\text { Mean } \pm \text { SD } \\
\text { Range }\end{array}$ & $\begin{array}{l}1.37 \pm 1.12 \\
0.15-3.79\end{array}$ & - & - \\
\hline
\end{tabular}

Radiation-exposed workers were drawn from various professions, including, among others, radiological doctors, nurses, radiographers, and $\mathrm{X}$-ray officers, while controls include, for instance, office workers, nurses, physicians, administration staff, and technicians. All radiation-exposed workers and controls were from the governmental hospitals in Indonesia.

\section{Hematological parameters analysis}

Hematological parameters test results are presented in Table 2. The values of some of the hematological parameters (RBC, WBC, HCT, $\mathrm{MCV}$, lymphocytes, and monocytes) were significantly different between radiation-exposed workers and to controls. The value of hematological parameters in radiation workers compared to controls were as follows: RBC $5.87 \pm 1.64$ versus $5.26 \pm 1.00, \mathrm{P}=0.04$; WBC $6.19 \pm 2.24$ versus $7.09 \pm 1.85, \mathrm{P}<0.0001 ; \mathrm{HCT} 42.66 \pm 5.08$ versus $44.32 \pm 5.04, \mathrm{P}=0.03 ; \mathrm{MCV} 85.81 \pm 6.15$ versus $88.01 \pm 5.95, \mathrm{P}=0.007$; lymphocytes $1.83 \pm 1.87$ versus $2.06 \pm 0.65, \mathrm{P}<0.0001$; and: monocytes $0.84 \pm 1.16$ versus $0.62 \pm 0.25, \mathrm{P}=0.01$. 
Table 2. Hematological parameters of radiation-exposed workers compared with the control group.

\begin{tabular}{|c|c|c|c|}
\hline \multirow[t]{2}{*}{$\begin{array}{c}\text { Hematological } \\
\text { parameters (HPs) count }\end{array}$} & $\begin{array}{l}\text { Exposed } \\
\text { workers }\end{array}$ & Controls & \multirow[t]{2}{*}{ P-value } \\
\hline & Mean \pm SD & Mean \pm SD & \\
\hline $\mathrm{Hb}(\mathrm{g} / \mathrm{dL})$ & $13.67 \pm 1.82$ & $13.91 \pm 1.86$ & 0.32 \\
\hline $\mathrm{RBCs}^{*}\left(\right.$ count $\left.\times 10^{6} / \mu \mathrm{L}\right)$ & $5.87 \pm 1.64$ & $5.26 \pm 1.00$ & 0.04 \\
\hline WBCs* $\left(\right.$ count $\left.\times 10^{3} / \mu \mathrm{L}\right)$ & $6.19 \pm 2.24$ & $7.09 \pm 1.85$ & $<0.0001$ \\
\hline PLT (count $\left.\times 10^{3} / \mu \mathrm{L}\right)$ & $266.33 \pm 66.58$ & $255 \pm 71.4$ & 0.13 \\
\hline $\operatorname{HCT}^{*}(\%)$ & $42.66 \pm 5.08$ & $44.32 \pm 5.04$ & 0.03 \\
\hline $\mathrm{MCV} *(\mathrm{fL})$ & $85.81 \pm 6.15$ & $88.01 \pm 5.95$ & 0.007 \\
\hline MCH (pg) & $27.47 \pm 2.87$ & $27.76 \pm 2.57$ & 0.44 \\
\hline $\mathrm{MCHC}(\mathrm{g} / \mathrm{dL})$ & $32.15 \pm 2.36$ & $31.46 \pm 1.39$ & 0.13 \\
\hline RDW (\%) & $13.22 \pm 1.02$ & $12.93 \pm 0.92$ & 0.06 \\
\hline MPV (fL) & $7.83 \pm 0.84$ & $7.98 \pm 0.69$ & 0.23 \\
\hline PDW (\%) & $12.48 \pm 2.12$ & $12.38 \pm 1.66$ & 0.78 \\
\hline $\begin{array}{l}\text { Lymphocytes* } \\
\left(\text { count } \times 10^{3} / \mu \mathrm{L}\right)\end{array}$ & $1.83 \pm 1.87$ & $2.06 \pm 0.65$ & $<0.0001$ \\
\hline $\begin{array}{c}\text { Monocytes* } \\
\left(\text { count } \times 10^{3} / \mu \mathrm{L}\right)\end{array}$ & $0.84 \pm 1.16$ & $0.62 \pm 0.25$ & 0.01 \\
\hline $\begin{array}{c}\text { Granulocytes } \\
\left(\text { count } \times 10^{3} / \mu \mathrm{L}\right)\end{array}$ & $4.78 \pm 2.1$ & $4.58 \pm 1.45$ & 0.72 \\
\hline
\end{tabular}

\section{Correlation between years of employment and equivalent dose to hematological parameters}

The number of years of employment for radiation workers were in 2-35 range with an average working period of $16.95 \pm 8.46$. The equivalent dose for radiation workers was 0.15-3.79 $\mathrm{mSv}$ with an average dose of $1.37 \pm$ $1.12 \mathrm{mSv}$. Linear regression analyses were performed to examine the correlation between years of employment and equivalent dose on one hand and hematological parameters on the others. Table 3 shows that no significant relationship was found between years of employment, equivalent dose, and hematological parameters $(\mathrm{P}>0.05)$, except for RBCs. There is a significant correlation between the equivalent dose and red blood cell count parameter $(\mathrm{P}=0.001)$, as shown in Fig. 2 .

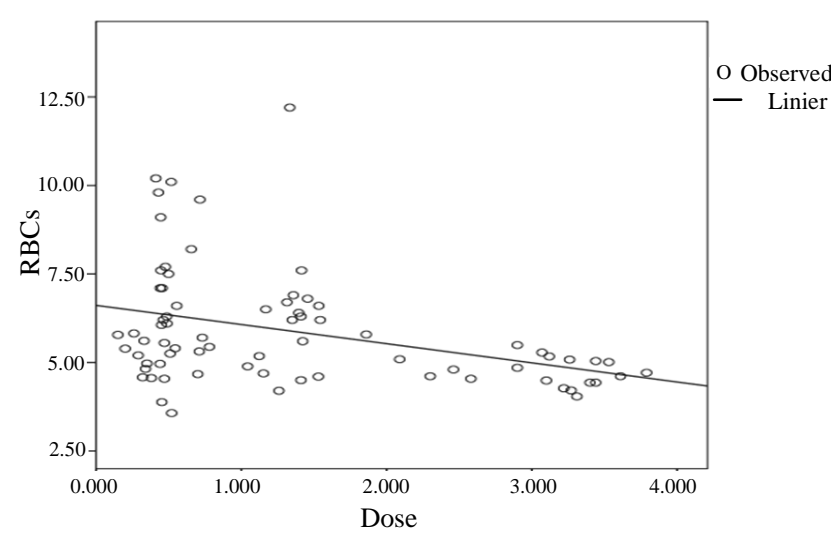

Fig. 2. Scatter plot: RBCs vs. Equivalent Dose (mSv). Model equation $\mathrm{RBCs}=\mathrm{Y}=-0.541 \mathrm{X}+6.61, \beta=-0.366(\mathrm{P}$-value $=$ 0.001 ), $\mathrm{N}=74$, (RBCs: Red blood cells; $\mathrm{mSv}$ : millisievert).
Some previous studies stated that irradiation has some dose-dependent and time-dependent adverse effects on the erythrocytes [16]. IR causesa significant reduction in blood cell count in adose-dependent manner, which may be considered a potential health risk during exposure to irradiation [17].

\section{DISCUSSION}

Long-term exposure to low doses of ionizing radiation may adversely affect human cells and tissues of hospital radiation workers, especially in peripheral blood cells count [8]. The novelty of the research is the examination of the hematological effects and susceptibility in individuals exposed to low-dose ionizing radiation, especially in hospital radiation workers in Indonesia. Thus, this study has recruited radiation workers who work in the radiological installation of governmental hospitals and continuously exposed to ionizing radiation which typically consist of X-ray, gamma $\left({ }^{131} \mathrm{I},{ }^{99} \mathrm{Tc}\right)$, and alpha radiations. The sampling method is based on a survey of radiation workers at several governmental hospitals in Indonesia, in which we obtained 74 radiation workers and 83 controls. In this study, the levels of fourteen different hematological parameters were measured and the correlations between number of years of employment as well as equivalent dose and hematological parameters were calculated.

Hematopoietic stem cells (HSCs) injury is the primary cause of death after accidental or intentional exposure to a moderate or high dose of ionizing radiation. Radiation exposure can cause damage to hematopoietic stem cells and generate several kinds of free radicals in living cells. These free radicals/reactive oxygen species (ROS) can cause apoptosis in hematopoietic cells, decreasing the ability of the cells to proliferate. This is very likely to occur because the hematopoietic system is one of the most radiosensitive systems. This system also provides blood clots for whole blood vessels [18].

Table 2 indicates that the levels of WBC, $\mathrm{HCT}, \mathrm{MCV}$, and lymphocytes were significantly lower in radiation-exposed workers than in control, whereas the levels of RBC and monocytes were significantly higher in radiation-exposed workers compared to control $(\mathrm{P}<0.05)$. A previous study by Shahid et al. (2014) stated that the levels of RBC and lymphocytes were higher in radiation workers. The possible reason is that hematological parameters of radiation workers, except $\mathrm{RBC}$ and monocytes, are more sensitive and easily changed 
due to the radiation exposure. For example, although mature platelets are less sensitive to ionizing radiation, stem cells are very radiosensitive. The megakaryocytic stem cells can decrease due to exposure to high-dose ionizing radiation. It results in lower platelet levels in radiation workers than in controls. Erythropoietic cells in human always produce mature erythrocytes to replace damaged erythrocytes. It makes the process of new erythrocyte cells formation faster. Immature erythroid cells such as erythroblast and basophilic proerythroblast are more sensitive than other erythroid cells such as normoblasts and reticulocytes. These immature cells more easily experience apoptosis (programmed cells death), which triggers hematopoietic stem cells to increase cells proliferation and generate new red blood cells $[14,19]$.

The level of white blood cells (WBCs) decreased after radiation exposure. It seems that WBCs are the most radiosensitive to $\gamma$-ray radiation compared to other blood constituents. Thrall et al. (2013) conducted a research using mouse models and showed a decline in the WBC levels significantly after radiation treatment with multilevel irradiation doses, except in the 0.25 Gy group. A study by Caciari et al. (2012) indicated that the mean of total WBCs significantly declined in exposed workers compared to controls. It is caused by exposure to ionizing radiation for a long time and loss of stem cells through the mechanism of apoptosis and decreased cell proliferation capacity. El-Shanshoury et al. (2016) stated that a significant decrease in WBC levels occurred 24 hours after irradiation, starting from $0.3 \mathrm{~Gy}$. The significance level increased with increasing doses and the degradation rate was 15 times higher than recovery rates. A similar mechanism also occurs on HCT, MCV, and lymphocytes levels [20-23]. On the contrary, an increase in monocyte level due to radiation exposure shows a compensatory mechanism performed by the human body (bone marrow) to maintain monocyte levels in a balanced position. The mechanism is very important since monocytes play an important role in the human immune system [14].

Table 3 shows the correlation and relationship analysis between years of employment and equivalent dose to hematological parameters. A significant correlation occurred between RBC level and equivalent dose $(\mathrm{P}=0.001)$ with the model equation is $Y=-0.541 \mathrm{X}+6.61$. It means there is a negative correlation between equivalent dose and RBC level. There is a decline in RBC level of $5.41 \times 10^{5} / \mu \mathrm{L}$ per $1 \mathrm{mSv}$ increase of radiation dose. Sanzari et al. (2014) suggested that a significant decline in blood cell counts after ionizing radiation exposure depends on dose [24]. Irradiation causes several adverse effects depending on the dose and duration of exposure to erythrocytes. In this study, a significant correlation occurred between radiation doses and RBC level; on the contrary, there is no significant correlation between radiation doses and years of employment. Xu et al. (2012) also stated that alteration on the structure and shape of red blood cells can be caused by radiation exposure, although it is still unclear and depends on doses treatment and certain storage periods [16].

Several previous studies related to the effect of radiation doses on $\mathrm{RBC}$ levels have been carried out. Ismail et al. (2012) found that changes of the density of WBCs, PLTs, and RBCs were variable due to the exposure dose rate. The optimum exposed dose rate to make more adverse effects on the leukemia blood samples began at the radiation dose rate of $43.25 \pm 1.206 \mu \mathrm{Sv} / \mathrm{h}$ for males and females. Surely, it needs to be considered from the level of DNA damage, especially double-strand break [25]. Furthermore, several types of single nucleotide polymorphisms indicate an association with the level of DNA damage on cancer patients and play a role in the risk of obesity in Javanese ethnicity of Indonesia [26, 27]. It is necessary to investigate the relationship between changes in hematological parameters and the level of DNA damage caused by exposure to ionizing radiation.

Table 3. Correlation between years of employment, equivalent dose, and hematological parameters in radiation exposed workers group using linear regression analysis test.

\begin{tabular}{ccccccc}
\hline \multirow{2}{*}{$\begin{array}{c}\text { Hematological } \\
\text { Parameters }\end{array}$} & \multicolumn{3}{c}{ Years of Employment (years) } & \multicolumn{3}{c}{ Equivalent Dose (mSv) } \\
\cline { 2 - 7 } & $\beta$ & $\mathrm{P}$ & Model Equation & $\beta$ & $\mathrm{P}$ & Model Equation \\
\hline RBCs & 0.025 & 0.833 & $\mathrm{Y}=0.005 \mathrm{X}+5.79$ & -0.366 & 0.001 & $\mathrm{Y}=-0.541 \mathrm{X}+6.61$ \\
WBCs & 0.113 & 0.34 & $\mathrm{Y}=0.03 \mathrm{X}+5.68$ & 0.124 & 0.291 & $\mathrm{Y}=0.252 \mathrm{X}+5.84$ \\
HCT & -0.029 & 0.81 & $\mathrm{Y}=-0.017+42.95$ & -0.195 & 0.095 & $\mathrm{Y}=-0.895 \mathrm{X}+43.89$ \\
MCV & 0.028 & 0.81 & $\mathrm{Y}=0.02 \mathrm{X}+85.47$ & 0.131 & 0.264 & $\mathrm{Y}=0.73 \mathrm{X}+84.81$ \\
Lymphocytes & 0.000 & 0.99 & $\mathrm{Y}=\mathrm{X}+1.83$ & -0.068 & 0.566 & $\mathrm{Y}=-0.115 \mathrm{X}+1.98$ \\
Monocytes & 0.016 & 0.895 & $\mathrm{Y}=0.002 \mathrm{X}+0.807$ & -0.092 & 0.436 & $\mathrm{Y}=-0.096 \mathrm{X}+0.975$ \\
\hline
\end{tabular}




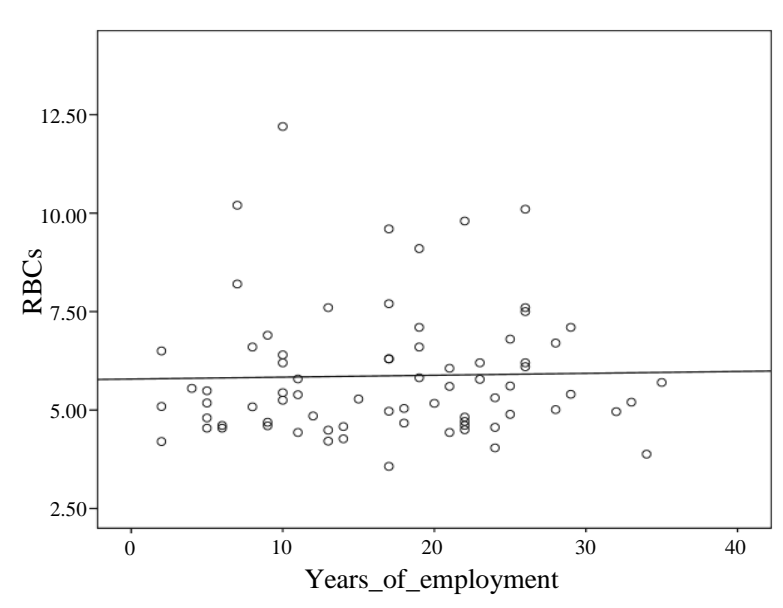

Fig. 3. Scatter plot: RBCs vs. years of employment. Model equation $\mathrm{RBCs}=\mathrm{Y}=0.005 \mathrm{X}+5.787, \beta=-0.025$ $(\mathrm{P}$-value $=0.417), \mathrm{N}=74$.

\section{CONCLUSION}

In conclusion, our study reports that RBC and monocyte values were significantly higher in radiation-exposed workers compared to controls, whereas WBC, HCT, MCV, and lymphocyte values were significantly lower in radiation-exposed workers compared to controls. There is a significant correlation between equivalent dose and red blood cells $(\mathrm{RBCs})$ parameter $(\mathrm{P}=0.001)$ with a decline in $\mathrm{RBC}$ level of $5.41 \times 10^{5} / \mu \mathrm{L}$ per $1 \mathrm{mSv}$ increase of radiation dose. The present study recommends that further studies should include greater sample sizes and inclusion of various independent variables (genetic polymorphism, chromosome aberration, micronuclei frequency) to study the long-term effects of low-dose radiation exposure on radiationexposed workers.

\section{ACKNOWLEDGMENT}

The authors would like to thank the radiationexposed workers who agreed to participate in this study and their colleagues in Medical Nuclear Technique and Radiobiology Division for their work and support. This research was fully funded by the Center for Radiation Safety Technology and Metrology, National Nuclear Energy Agency of Indonesia.

\section{REFERENCES}

1. N. Ossetrova, D.J. Sandgren, S. Gallego et al., Health Phys. 98 (2010) 204.

2. T.M. Fliedner and D.H. Graessle, DoseResponse 10 (2012) 644.
3. A.H. Ismail and M.S. Jaafar, Appl. Radiat. Isot. 69 (2011) 559.

4. G.A. Thomas and P. Symonds, Clinical Oncology 28 (2016) 231.

5. M. Verheij and H. Bartelink, Cell Tissue Res. 301 (2000) 133.

6. N. Dainiak, Experimental Hematology 30 (2002) 513.

7. L. Shao, Y. Luo, and D. Zhou, Antioxidants Redox Signaling, 20 (2014) 1447.

8. M. Alnahhal, Y. Alajeramy, S.A. Mostafa et al., Am. J. Med. and Med. Sci., 7 (2017) 238.

9. H.N.E. Surniyantoro, Y. Lusiyanti, T. Rahardjo et al., Atom Indonesia 44 (2018) 105.

10. H.N.E. Surniyantoro, Y. Lusiyanti, T. Rahardjo et al., Biodiversitas J. Biol. Div. 19 (2018) 1676.

11. M.R. Oskouii, S. Refahi, M. Pourissa et al., Life Sci. J. 10 (2013) 58.

12. M.B. Khorrami and B. Riahi-Zanjani, Archives 2 (2015) 138.

13. M. Shaffie, E. Hossienzhad, H. Vafapour et al., Global Journal of Health Science 8 (2016) 232.

14. S. Shahid, N. Mahmood, M.N. Chaudhry et al., FUUAST Journal of Biology 4 (2014) 135.

15. P. Klucinski, B. Mazur, L. Sedek et al., Int. J. Occup. Med. Environ. Health. 27 (2014) 467.

16. D. Xu, M. Peng, Z. Zhang et al., Blood Transfus. 10 (2012) 321.

17. H. El-Shanshoury, G. El-Shanshoury and A. Abaza, J. Rad. Res. App. Sci. 9 (2016) 282.

18. O.A. Smirnova, Environmental Radiation Effects on Mammals-A Dynamical Modeling Approach, Springer, New York (2010) 1.

19. J. Domen and I.L. Weissman, J. Exp. Med., 192 (2000) 1707.

20. J.K. Sanzari, X.S. Wan, G.S. Krigsfeld et al., Gravitational and Space Research 1 (2013) 79.

21. K.D. Thrall, J. Lovaglio, M.K. Murphy et al., Health Phys. 105 (2013) 245.

22. T. Caciari, A. Capozzella, F. Tomei et al., Annali Di Igiene 24 (2012) 465. 
23. D.H. Graessle, Br. J. Radiol. 26 (2002) 202.

24. J.K. Sanzari, K.A. Cengel, X.S. Wan et al., Life Sciences in Space Research 2 (2014) 86.

25. A.H. Ismail, M.A. Hamad and E.M.T. Harki, Open J. Biophysics 2 (2012) 130.
26. H.N.E. Surniyantoro, N. Rahajeng, Y. Lusiyanti et al., Biodiversitas J. Biol. Div. 20 (2019) 2128.

27. H.N.E. Surniyantoro, A.H. Sadewa and P. Hastuti, Kobe J. Med. Sci. 64 (2018) 64. 